\title{
Pektus ekskavatumda Nuss tekniğinin farklı yaş gruplarında klinik sonuçları
}

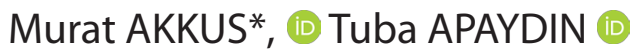

Mehmet Akif Ersoy Training and Research Hospital, Department of Thoracic Surgery, Istanbul/TURKEY

\begin{abstract}
Aim: In 1998, Donald Nuss suggested the insertion of a metal bar behind the sternum for pectus excavatum as a minimally invasive technique. However, data regarding the relation between the age of the patient and clinical results of repair is limited. Aim of this study is to compare the clinical results of Nuss surgery for pectus excavatum in different age groups, to point out the optimal range of age for this procedure.
\end{abstract}

Material and Methods: From February 2012 to January 2020, data regarding 140 patients have been treated with Nuss surgery. We classified patients into three groups: patients younger than 15 years (group A), patients between 15 and 20 years (group B); and patients older than 20 years up to 40 years (group C) retrospectively. We evaluated patients' demographics, and compared results of surgery, duration of hospitalization and complication rates.

Results: One hundred ten patients were male and 30 were female. Male patients, clinical symptomatic patients with dyspnea in the preoperative period were seen more frequently in patients with older age, and each were statistically significant ( $p: 0.003$ ). In the early 30-day postoperative period, no mortality was observed. The most frequent postoperative complications were observed in group C (40,9\%), followed by group B (18,2\%) and group A (9,6\%)(p:0.007). In logistic regression analysis, postoperative complications increased significantly in patients older than 20 years (p:0.003). Brace therapy was performed for 2 cases in Group A for recurrence after bar removal which occurred in adolescant period.

Conclusion: Nuss procedure can be recommended with low complication rates, short term hospitalization and high grade of success. Although the childhood period seems to be more suitable regarding the complications, surgery can be preferred with low recurrence rates in adolescant period.

Keywords: nuss procedure; pectus excavatum; minimally invasive repair of pectus excavatum

Corresponding author*: Murat AKKUS, Mehmet Akif Ersoy Training and Research Hospital, Department of Thoracic Surgery, Istanbul/TURKEY 


\section{Öz}

Amaç: 1998 yılında Donald Nuss minimal invaziv teknik olarak pektus ekskavatumda sternum arkasına metal bar yerleştirilmesini önermiş̧ir. Bununla beraber hastaların yaşları ve klinik sonuçları ile ilgili veriler sınırlıdır. Bu çalışmanın amacı, farklı yaş grupları arasında pektus ekskavatumda Nuss cerrahisinin klinik sonuçlarııı karşılaştırmak, bu prosedür için en uygun yaş aralığını vurgulamaktır.

Gereç ve Yöntemler: Şubat 2012 ile Ocak 2020 yılları arasında Nuss operasyonu ile tedavi edilen 140 olgu çalışmaya alındı. Olgular 3 grup olarak sınıfandırıldı: 15 yaşından küçük olgular (grup A), 15-20 yaş aralığında olanlar (grup B), 20 yaşından büyük 40 yaşa kadar (grup C) olarak sıralandı. Hastaların, demografik yapıları, cerrahi sonuçları, hastanede yatış süreleri ve komplikasyon oranları değerlendirilerek karşılaştıııldı.

Bulgular: Yüz on hasta erkek, 30 hasta kadındı. Erkek olgular, solunum sıkıntısı klinik şikayeti olan olgular en sık ileri yaş grubunda görüldü ve istatistiksel olarak anlamlı idi (p:0.003). Erken postoperatif 30 gün ölüm izlenmedi. En sık komplikasyon grup C $(\% 40,9)$, takiben grup B $(\% 18,2)$ ve grup A $(\% 9,7)$ görüldü (p:0.007). Lojistik regresyon analizinde 20 yaş üstü olan olgularda postoperatif komplikasyonlar anlamlı olarak yüksek bulundu (p:0.003). Ergenlik döneminde bar çıkarılması sonrası nüks gelişen 2 grup A olgusuna Brace tedavisi uygulandı.

Sonuç: Nuss tekniği, düşük komplikasyon oranı, kısa süreli hastanede yatış ve tatminkar sonuçları ile tavsiye edilebilir. Çocukluk dönemi, komplikasyonlara bağlı uygun gibi görülmesine rağmen cerrahi, nüks oranı düşüklüğü nedeniyle ergenlik döneminde tercih edilebilir.

Anahtar kelimeler: nuss tekniği; pektus ekskavatum; minimal invaziv onarım pektus cerrahisi

\section{Introduction}

In 1998, Donald Nuss suggested the insertion of a metal bar behind the sternum for pectus excavatum as a minimally invasive technique[1]. Since then, many articles have been published about this technique[2]. However, data regarding the relation between the age of the patient and clinical results of repair is limited. Optimal age reported in the literature is between 12 and 16 years [3].However, many clinicians perform this technique in both younger patients and adults [4-6]. Operations in adults have been reported to have higher rates of complication rates [3].

Aim of this study is to compare the clinical results of Nuss surgery for pectus excavatum between pediatric, adolescant and adult age groups, to point out the optimal range of age for this procedure.

\section{Material and Methods}

From February 2012 to January 2020, 140 patients have been treated with Nuss surgery in tertiary central hospital. We classified patients into three groups: patients younger than 15 years, patients between 15 and 20 years; and patients between 20 and 40 years. We evaluated patients' demographics, and compared results of surgery, duration of hospitalization and complication rates.
Degree of pectus excavatum was confirmed with computed tomography, in which the pectus index was determined by dividing the width of the chest wall at the widest point by the distance between the posterior side of sternum and anterior side of spine.

Three age groups were generated. Group A was composed of 52 patients between 3 and 14 years (mean $11 \pm 3$ years). Group B composed of 66 patients between 15 and 20 years (mean $16.6 \pm 1.3$ years). Group $C$ composed of 22 patients between 21 and 40 years (mean $28,5 \pm 7,2$ years). Ratio of males to females was 1.7(33/19) in Group A, 6.3(57/9) in Group B, 10(20/2) in Group C.

All patients were examined in the outpatient clinic in the preoperative period. Size of the chest wall was measured. Presence of asymmetry was checked. Depth of the sternal depression was also evaluated. Haller index was measured from computed tomography scans. Haller index was defined as the ratio of transverse diameter of the chest by the anterior posterior distance that shows the smallest distance between the anterior surface of the vertebra and posterior surface of the sternum.

All patients were examined with routine blood tests, pulmonary function tests, electrocardiogram, transthoracic echocardiography and thoracic computed tomography. Preoperative clinical data of patient groups is shown in Table 1. Bars composed of nickel, chromium and iron were implemented in all patient groups. 


\begin{tabular}{|c|c|c|c|c|c|}
\hline \multicolumn{6}{|c|}{ TABLE 1: PREOPERATIVE CLINICAL DATA OF PATIENT GROUPS } \\
\hline & $\begin{array}{l}\text { TOTAL } \\
(\mathrm{N}: 140)\end{array}$ & $\begin{array}{c}\text { GROUP A } \\
(\mathrm{N}: 52)\end{array}$ & $\begin{array}{c}\text { GROUP B } \\
(\mathrm{N}: 66)\end{array}$ & $\begin{array}{l}\text { GROUP C } \\
(\mathrm{N}: 22)\end{array}$ & $\mathrm{P}$ \\
\hline AGE & $\begin{array}{c}16,4 \pm 6,8 \\
(3-40)\end{array}$ & $\begin{array}{c}11 \pm 3 \\
(3-14)\end{array}$ & $\begin{array}{c}16,6 \pm 1,3 \\
(15-20)\end{array}$ & $\begin{array}{c}28,5 \pm 7,2 \\
(21-40)\end{array}$ & $<0,001^{\mathrm{cs}}$ \\
\hline \multicolumn{6}{|l|}{ SEX } \\
\hline FEMALE & $30(21,4 \%)$ & $19(36,5 \%)$ & $9(13,6 \%)$ & $2(9,1 \%)$ & $0,003^{c s}$ \\
\hline MALE & $110(78,6 \%)$ & $33(63,5 \%)$ & $57(86,4 \%)$ & $20(90,9 \%)$ & \\
\hline SYMPTOMS & $77(55 \%)$ & $19(36,5 \%)$ & $42(63,6 \%)$ & $16(72,7 \%)$ & $0,003 \mathrm{k}^{\mathrm{w}}$ \\
\hline DYSPNEA & $29(20,7 \%)$ & $4(7,7 \%)$ & $16(24,2 \%)$ & $9(40,9 \%)$ & $0,003 \mathrm{k}^{\mathrm{w}}$ \\
\hline CHEST PAIN & $41(29,3 \%)$ & $12(23,1 \%)$ & $23(34,8 \%)$ & $6(27,3 \%)$ & $0,368^{\mathrm{kw}}$ \\
\hline FATIGUE & $3(2,1 \%)$ & $1(1,9 \%)$ & $1(1,5 \%)$ & $1(4,5 \%)$ & $0,999^{\mathrm{kw}}$ \\
\hline ARRHYTMIAS & $4(2,9 \%)$ & $2(3,8 \%)$ & $2(3 \%)$ & 0 & $0,840^{\mathrm{kw}}$ \\
\hline
\end{tabular}

Indications for surgery were cosmetic reasons, pectus index $>3.25$ or cardiac compression. Surgery was performed with general anesthesia and Nuss technique described by Donald Nuss in 1998[1]. Patients were followed at 1,3,6,12 and 24 months after the first operation and 1 and 12 months after removal of the bars.

\section{Surgical Procedure}

Two small incisions were made on each side of the chest wall on the midaxillary lines at the level of deepest chest wall depression. Introducer was placed into the right chest wall using videothoracoscopy and carbondioxide insufflation. After the introducer was passed from the right to the left chest wall from the highest hinge point, introducer was lifted and pressed the sternum to bring the proper shape to the sternum. A nylon tape was tied to the end of introducer and introducer was pulled from the contralateral side. Bent Nuss bars were binded to the end of the nylon tape, then bars were pulled with the help of the tape to the other side of chest wall. Bars were turned 180 degrees retrosternally to pick the sternum up. One fixation stabilizer were placed at the end of the bar on the right or left side to avoid bar dislocation.The number of the bars used is shown in Table 2. The bars implemented were removed 3 years after the first operation.

\begin{tabular}{|c|c|c|c|c|c|}
\hline & $\begin{array}{c}\text { TOTAL (N:140) } \\
\pm \text { SD(MINIMUM,MAXIMUM) }\end{array}$ & $\begin{array}{l}\text { GROUP A } \\
(\mathrm{N}: 52)\end{array}$ & $\begin{array}{l}\text { GROUP B } \\
(\mathrm{N}: 66)\end{array}$ & $\begin{array}{l}\text { GROUP C } \\
(\mathrm{N}: 22)\end{array}$ & $P$ \\
\hline HALLER INDEX & $\begin{array}{l}2,9 \pm 0,4 \\
(2,5-3,5)\end{array}$ & $2,9 \pm 0,4(2,5-3,5)$ & $2,8 \pm 0,4(2,5-3,5)$ & $2,8 \pm 0,4(2,5-3,5)$ & $0,481^{\mathrm{kw}}$ \\
\hline \multicolumn{6}{|l|}{$\begin{array}{l}\text { NO. OF BARS } \\
\text { IMPLEMENTED }\end{array}$} \\
\hline 1 & $109(77,9 \%)$ & $47(90,4 \%)$ & $47(71,2 \%)$ & $15(68,2 \%)$ & $0,004^{\mathrm{kw}}$ \\
\hline 2 & $29(20,7 \%)$ & $5(9,6 \%)$ & $19(28,8 \%)$ & $5(22,7 \%)$ & \\
\hline 3 & $2(1,4 \%)$ & 0 & 0 & $2(9,1 \%)$ & \\
\hline $\begin{array}{l}\text { DURATION OF } \\
\text { OPERATION(MIN.) }\end{array}$ & $60,3 \pm 21,1(15-120)$ & $58,5 \pm 21,1(15-120)$ & $59,2 \pm 19,7(30-120)$ & $68,2 \pm 24,4(30-120)$ & $0,300^{\mathrm{kw}}$ \\
\hline RECURRENCE & 2 & 2 & 0 & 0 & $0.98^{\mathrm{kw}}$ \\
\hline
\end{tabular}

\section{Statistical Analyses}

Statistical analysis was made using IBM SPSS Statistics for Windows, Version 23.0 (IBM Corp., Armonk, NY). Pearson chi-square test was performed for categorical variables. The normality assumptions were controlled by the Shapiro-Wilk test. Kruskal Wallis test was used for comparison of non- parametric variables between groups and Bonferroni-Dunn test was used as a post-hoc test for significant cases. Binary logistic regression analysis was used to determine the effect of the study groups on postoperative complication. Data are expressed as $\mathrm{n}(\%)$ or mean $\pm \mathrm{SD}$ (range), as appropriate. $\mathrm{P}$ values $<0.05$ were considered statistically significant. 


\section{Results}

One hundred ten patients were male and 30 were female. Range of age was 3 and 40 years (mean, 16.4+-6.8 years). Male patients, symptomatic patients and dyspnea in the preoperative period were seen more frequently in patients with older age, each were statistically significant (p:0.003) (Table 1). Haller index isn't shown to have a relation with age (p:0,481). Duration of operation increased in patient groups with older age, but this wasn't statistically significant ( $p: 0,300)$. In the patient groups with older age, number of bars implemented increased significantly (p:0.004) as shown in Table 2. In the early 30-day postoperative period, no mortality was observed.
The most frequent postoperative complications were observed in group C (40,9\%), followed by group B (18,2\%) and group A (9,6\%), (p:0.007). There were no significant difference between postoperative complication rates of three groups shown in Table 3. Pleural catheter drainage was performed for pleural effusion and dyspnea for one patient from group B. Brace therapy was performed for 2 cases in Group A for recurrence after bar removal which occurred in adolescant period. Duration of hospitalization increased in older ages, but this wasn't statistically significant (p:0,552) (Table 3). In logistic regression analysis, postoperative complications increased significantly in patients older than 20 years (p:0.003) (Table 4).

\begin{tabular}{|c|c|c|c|c|c|}
\hline & $\begin{array}{l}\text { TOTAL } \\
(\mathrm{N}: 140)\end{array}$ & $\begin{array}{c}\text { GROUP A } \\
\text { (N:52) }\end{array}$ & $\begin{array}{c}\text { GROUP B } \\
(\mathrm{N}: 66)\end{array}$ & $\begin{array}{c}\text { GROUP C } \\
(\mathrm{N}: 22)\end{array}$ & $P$ \\
\hline COMPLICATIONS (TOTAL) & $26(18,6 \%)$ & $5(9,6 \%)$ & $12(18,2 \%)$ & $9(40,9 \%)$ & $0,007^{\mathrm{cs}}$ \\
\hline PNEUMOTHORAX & $10(7,1 \%)$ & $2(3,8 \%)$ & $4(6,1 \%)$ & $4(18,2 \%)$ & $0,096^{\text {cs }}$ \\
\hline PLEURAL EFFUSION & $4(2,9 \%)$ & 0 & $3(4,5 \%)$ & $1(4,5 \%)$ & $0,374^{\mathrm{cs}}$ \\
\hline BAR DISLOCATION & $5(3,6 \%)$ & 0 & $3(4,5 \%)$ & $2(9,1 \%)$ & $0,150^{\text {cs }}$ \\
\hline WOUND INFECTION & $2(1,4 \%)$ & 0 & $1(1,5 \%)$ & $1(4,5 \%)$ & $0,647^{\mathrm{cs}}$ \\
\hline BAR ALLERGY & $7(5 \%)$ & $3(5,8 \%)$ & $2(3 \%)$ & $2(9,1 \%)$ & $0,610^{\text {cs }}$ \\
\hline COSTA FRACTURE & $3(2,1 \%)$ & 0 & $1(1,5 \%)$ & $2(9,1 \%)$ & $0,064^{\mathrm{cs}}$ \\
\hline HEMATOMA & $2(1,4 \%)$ & 0 & $1(1,5 \%)$ & $1(4,5 \%)$ & $0,647^{\mathrm{cs}}$ \\
\hline DURATION OF HOSPITALIZATION & $5,5 \pm 2,5(2-18)$ & $5,3 \pm 2,1(2-14)$ & $5,5 \pm 2,5(2-18)$ & $6,2 \pm 3(3-14)$ & 0,552 \\
\hline
\end{tabular}

$\begin{aligned} & \text { Tablo 4-Logistic regression analysis for postoperative com- } \\
& \text { plications }\end{aligned}$
\begin{tabular}{lcc} 
Group & OR $(95 \% \mathrm{Cl})$ \\
Group A & Reference & - \\
\hline Group B & $2,089(0,686-6,365)$ & 0,195 \\
Group C & $6,508(1,857-22,804)$ & 0,003
\end{tabular}

\section{Discussion}

Results of Nuss operation can vary between age groups. Data is less regarding the ideal age. In Donald Nuss' first original article, all cases were between 5 and 15 years [1]. Mean age for surgery progressed in the course of time. Etiology for this increment is reported as acquired thoracic dystrophy related with the prior radical excisional repairs of pectus [7]. Mean age has progressed to 14.4 years in USA in 2009 [8]. New data from South Korea reported that reconstruction can be performed in any age after 3 years [9]. The quantity of force needed for reconstruction at the younger age is less than half that of teens, and almost a third the force required compared to adult patients [10]. Besides, a trace of healing in scoliosis may be observed when done at a younger age [11]. Regarding the extended series from Korea, it's unnecessary to limit surgery to a specific age. On the other hand, adults have been successfully operated late in life [12].

In our study, we analyzed the results of Nuss surgery for pectus excavatum in different age groups. Group A composed of children, group $B$ composed of adolescent patients until the completion of skeletal growth, and group C composed of adults. This classification is coherent with the consequtive phases of development and changes in the costal muscular chest wall architecture. A similar dispersion of study groups was used by Park and colleagues [9] and Kim and associates [13].

Referment with cosmetic complaints also increased significantly in other reports[2,3,4]. Zhang et al. [2] reported that usage of 2 and more than two bars increased significantly in adults. In our study, usage of 2 bars was much more in Group $B$ and $C$ although it was not statistically significant.

Postoperative morbidity was reported as \%35 in 238 patients in the literature. In our study, its frequency increased with advancing patient age similiar to the literature [14]. Mean 
number of postoperative complications of all groups was \%18.6 and it increased significantly in adult group (\%40.9) $(p<0.05)$. The most frequent complication in the early postoperative period was pneumothorax, which was significantly more frequent in patients between 20 and 40 years of age. The occurrence of this complication varies widely up to $\% 64$ in the literature [15-18]. Surgical intervention is generally unnecessary for postoperative pneumothorax, it's prone to spontaneous recovery. The most frequent reason may be considered as insufficient implentation of reexpansion procedures during surgery.

Pleural effusion also may have occurred secondary to the increased space after reparation of the sternal position with a similiar consideration[18,19]. Thoracentesis or chest tube drainage was performed. Massive pleural effusion was drained with pleural catheter in one patient from Group B. In the literature, the reported complication rate requiring intervention is between $0.6 \%$ and $16.7 \%[4,20]$.

In several reports, it is pointed out that proper fixation of the bar is very essential. [21,22]. It's suggestted that at least 2 bars should be used in elderly patients [4]. Sliding of bars were much more in Group C in our study but this wasn't statistically significant.

Increment in bar allergies is reported in the last years' articles. Metal alloy bars were used generally. We used alloys composed of nickel, chromium and iron. Rate of metal alloy bar allergies is about \%6.6 in several centers [23]. Rate of bar allergy was \%5 in our series and any difference wasn't observed between age groups.

Recurrence due to rapid growth after bar removal in the adolescant period or pectus carinatum deformity may be observed although the complication rate was low during childhood [24]. Recurrence was seen in two cases in our series and they were treated via brace therapy. For this reason, repair in the adolescant period is preferred unless a serious cardiac and respiratory insufficiency is observed [25].

Limitation: Single centered cases and unequal dispersion of the groups limits the study.

\section{Conclusion:}

Nuss surgery can be recommended with low complication rates, short term hospitalization and high grade of success. Although complication rates increase at the age of 20 and above, the values are at an acceptable level. Although the childhood period seems to be more suitable regarding the complications, adolescant period can be preferred with low recurrence rates.

\section{Declaration of conflict of interest}

The authors received no financial support for the research and/or authorship of this article. There is no conflict of interest

\section{References}

1. Nuss D, Kelly Jr RE, Croitoru DP, Katz ME. A 10-year review of a minimally invasive technique for the correction of pectus excavatum. Journal of pediatric surgery 1998; 33: 545-52.

2. Zhang D, Tang J, Ben X et al. Surgical correction of 639 pectus excavatum cases via the Nuss procedure. Journal of Thoracic Disease 2015; 7: 1595-605.

3. Pawlak K, Gasiorowski L, Gabryel P, Galecki B, Zielinski P, Dyszkiewicz W. Early and late results of the Nuss Procedure in Surgical Treatment of Pectus Excavatum in different age groups. Annals of Thoracic Surgery 2016; 102: 1711-6.

4. Pilegaard HK. Extending the use of Nuss procedure in patients older than 30 years. Eur J Cardiothorac Surg 2011; 40: 334-7.

5. Aronson DC, Bosgraaf RP, van der Horst C, Ekkelkamp S. Nuss procedure: pediatric surgical solution for adults with pectus excavatum. World J surg 2007; 31: 26-9.

6. Coln D, Gunning T, Rmasay M, Swygert T, Vera R. Early experience with the Nuss minimally invasive correction of pectus excavatum in adults. World J Surg 2002; 26: 1217-21.

7. Haller JA, Jr., Scherer LR, Turner CS, Colombani PM. Evolving management of pectus excavatum based on a single institutional experience of 664 patients. Ann Surg 1989; 209: 578-82

8. Papandria D, Arlikar J, Sacco Casamassima MG et al. Increasing age at time of pectus excavatum repair in children: emerging consensus? J Pediatr Surg 2013; 48: 191-6

9. Park HJ, Sung SW, Park JK, Kim JJ, Jeon HW, Wang YP. How early can we repair pectus excavatum: the earlier the better? Eur J Cardiothorac Surg 2012; 42: 667-72.

10. Fonkalsrud EW, Reemtsen B. Force required to elevate the sternum of pectus excavatum patients. J Am Coll Surg 2002; 195: 575-7.

11. Park HJ, Kim JJ, Park JK, Moon SW. Effects of Nuss procedure on thoracic scoliosis in patients with pectus excavatum. Journal of thoracic disease 2017; 9: 3810-6.

12. Jaroszewski DE, Ewais MM, Chao CJ et al. Success of Minimally Invasive Pectus Excavatum Procedures (Modified Nuss) in Adult Patients ( $>/=30$ Years). Ann Thorac Surg 2016. [9] Ewais MM, Chaparala S, Uhl R, Jaroszewski DE. Outcomes in adult pectus excavatum patients undergoing Nuss repair. Patient Relat Outcome Meas 2018; 9: 65-90 
13. Kim DH, Hwang JJ, Lee MK, Lee DY, Paik HC. Analysis of the Nuss procedure for pectus excavatum in different age groups. The Annals of thoracic surgery 2005; 80: 1073-7.

14. Mao YZ, Tang ST, Wang Y, Tong QS, Ruan QL. Nuss operation for pectus excavatum: a single-institution experience. World Journal of Pediatrics 2009; 5: 292.

15. Shu Q, Shi Z, Xu WZ, Li JH, Zhang ZW, Lin R, Zhu XK, Yu JG. Experience in minimally invasive Nuss operation for 406 children with pectus excavatum. World Journal of Pediatrics 2011; 7: 257.

16. Aronson DC, Bosgraaf RP, van der Horst C, Ekkelkamp S. Nuss procedure: pediatric surgical solution for adults with pectus excavatum. World journal of surgery 2007; 31: 26-9.

17. Bosgraaf RP, van der Horst C, Ekkelkamp S. Nuss procedure: pediatric surgical solution for adults with pectus excavatum. World journal of surgery $2007 ; 31: 26-9$

18. De Matos AC, Bernardo JE, Fernandes LE, Antunes MJ. Surgery of chest wall deformities. European Journal of Cardiothoracic Surgery 1997; 12: 345-50.

19. Cheng YL, Lee SC, Huang TW, Wu CT. Efficacy and safety of modified bilateral thoracoscopy-assisted Nuss procedure in adult patients with pectus excavatum. European journal of cardio-thoracic surgery $2008 ; 34:$ 1057-61.
20. Peter SD, Sharp SW, Ostlie DJ, Snyder CL, Holcomb III GW, Sharp RJ. Use of a subxiphoid incision for pectus bar placement in the repair of pectus excavatum. Journal of pediatric surgery 2010; 45: $1361-4$

21. ParkHJ, Chung WJ, Lee IS, Kim KT. Mechanism of bar displacement and corresponding bar fixation techniques in minimally invasive repair of pectus excavatum. Journal of pediatric surgery 2008; 43: 74-8.

22. Hebra A, Jacobs JP, Feliz A, Arenas J, Moore CB, Larson S. Minimally invasive repair of pectus excavatum in adult patients. The American Surgeon 2006; 72: 837-42.

23. Notrica DM. The Nuss procedure for repair of pectus excavatum: 20 error traps and a culture of safety. InSeminars in pediatric surgery $2019 ; 28: 72-77$

24. Notrica DM. Modifications to the Nuss procedure for pectus excavatum repair: A 20-year review. InSeminars in pediatric surgery $2018 ; 27: 133$

25. Nuss D. Minimally invasive surgical repair of pectus excavatum. InSeminars in pediatric surgery 2008; 17: 209-217 